\title{
Specific genotypes of plantain (Plantago lanceolata) vary in their impact on sheep urine volume and nitrification in the urine patch
}

\author{
H.G. JUDSON ${ }^{1}$, P.M. FRASER ${ }^{2}$, M.E. PETERSON ${ }^{2}$ and G.R. EDWARDS ${ }^{3}$ \\ ${ }^{1}$ Agricom, P.O Box 3761, Christchurch, New Zealand \\ ${ }^{2}$ Plant \& Food Research, Lincoln Private Bag 4704, Christchurch Mail Centre 8140, New Zealand \\ ${ }^{3}$ Agriculture and Life Sciences Faculty, Lincoln University, P.O. Box 84, Lincoln University, New Zealand \\ gjudson@agricom.co.nz
}

\begin{abstract}
Plantain has the potential to reduce nitrate leaching through a number of mechanisms. In an indoor study, sheep were offered either perennial ryegrass or different plantain genotypes while aiming to achieve similar dry matter and water intakes. Supplementary water was sprayed on the feed to achieve the latter objective. Animals fed two cultivars ('Tonic' and 'Agritonic', marketed as "Ecotains" with claims around the potential to reduce nitrate leaching, and breeding lines (from a breeding program aimed at improving aspects of leaching mitigation) produced significantly more urine (4925 and $4887 \mathrm{ml} /$ day, respectively) than those fed a range of commercial plantain cultivars (averaging 4333 $\mathrm{ml} /$ day) or perennial ryegrass $(3993 \mathrm{ml} /$ day $)$. These results suggest the plantains marketed as "Ecotains" and those in the environmental breeding program may have diuretic effects on sheep, thereby reducing the concentration of nitrogen in the urine. In a soil incubation experiment, urine from sheep grazing either perennial ryegrass or 'Agritonic' plantain was applied to soil microcosms ( $70 \mathrm{ml}$ vials containing $20 \mathrm{~g}$ of soil). Urine from sheep grazing the plantain, showed a slower overall nitrification rate (especially in the first 28 days post-application) when a significantly lower proportion of the urinary $\mathrm{N}$ was converted to nitrate. Both these observations support the use of specific genotypes of plantain to assist in reducing nitrate leaching.
\end{abstract}

Keywords: nitrate leaching, soil incubation, sheep, urine

\section{Introduction}

Regional councils in New Zealand are placing restrictions on nitrate $\left(\mathrm{NO}_{3}^{-}\right)$leaching losses from agricultural land with the aim of improving ground water quality. The predominant source of $\mathrm{NO}_{3}{ }^{-}$leaching in a grazing system is the urine patch with up to $90 \%$ of $\mathrm{N}$ leached to ground water coming from them (Ledgard et al. 2009). Thus, management options that reduce the nitrogen $(\mathrm{N})$ losses in animal urine will be beneficial to farmers concerned about these losses.

Plantain, (largely cultivar 'Tonic'), commercialised in New Zealand over 20 years ago (Stewart 1996), has become a successful forage plant for livestock, particularly sheep, beef cattle and deer. Plantain pastures provide benefits during lactation for ewes through improved intake, reduced faecal egg output (Judson et al. 2009) and increased milk production (Kenyon et al. 2010), and also for lamb finishing (Moorhead et al. 2002; Kemp et al. 2013) through improved liveweght gain (relative to perennial ryegrass pastures). Recently, "diverse" pastures containing ryegrass, clovers and forage herbs, including plantain, have been shown to reduce urinary $\mathrm{N}$ concentration in dairy cows (Totty et al. 2013). Initially, the focus was on pasture diversity per se rather than specific components of the pasture. A specific winter-active cultivar ('Tonic') of plantain (Plantago lanceolata) has become a common pasture species in New Zealand due to its excellent seasonal production, forage quality, palatability to livestock and performance in a wide number of environments. However, only recently its potential to reduce nitrate leaching from urine patches has been discovered (Carlton et al. 2018).

As a species, plantains include winter-dormant flat weeds and upright winter-active forage plants. For clarity, plantain in this paper refers to winter-active, upright and productive forage plantains, of which there are few in the world.

This paper presents a comparison of different genotypes in relation to their ability to initiate diuresis, and also evaluates one cultivar's ability to inhibit nitrification in the urine patch.

\section{Materials and methods Diuretic potency}

An autumn indoor sheep study was conducted at Lincoln University, New Zealand using two groups of 20 Romney-cross, 5-month-old, ewe lambs (about $44 \mathrm{~kg}$ average liveweight). Procedures were approved by the Lincoln University Animal Ethics Committee. Before this study started the animals grazed diploid perennial ryegrasses. Lambs were housed in metabolism crates and offered $6.5 \mathrm{~kg}$ fresh weight (FW) daily of perennial ryegrass (Lolium perenne) with no access to drinking water during a 4-day transition period. Lambs with similar average daily urine volumes during the 
transition period formed the two groups of 20 animals. The transition period was followed by three 3-day measurement periods (Period 1: 13th-16th March, Period 2: 20th-23rd March and Period 3: 27th-30th March). On the first day of each measurement period four lambs were randomly allocated to one of the 12 plantain cultivars or the diploid perennial ryegrass (cultivar 'Ceres One ${ }^{50}$ ') control treatment. Thus, Period 1 utilised the plantain cultivars 'Tonic', 'Tuatara', 'Hercules', 'Lancelot' and the control ryegrass; Period 2, 'Agritonic', 'PG718', 'Endurance', 'PG 702' and the control ryegrass; Period 3, 'Ranger', 'Boston', 'PG734', 'Elite 18 ' and the control ryegrass. The experiment was an unbalanced design because the same plantain cultivars were not used in each measurement period.

Forage, mechanically harvested the previous evening (approximately $6.5 \mathrm{~kg} \mathrm{FW}$ ) from a pre-harvest yield of about $2800 \mathrm{~kg} \mathrm{DM} / \mathrm{ha}$ (depending on the autumn activity of the cultivar) was stored at $5^{\circ} \mathrm{C}$ and offered each morning to provide a DM intake of $1.0 \mathrm{~kg} \mathrm{DM} /$ animal. A uniform water content for all forages was created for all animals by applying water (to achieve a water intake of $5.5 \mathrm{~L} / \mathrm{animal}$ ) to the surface of the feed using a spray bottle. Feed allocation (kg FW/day) and water volume applied to the feed surface was based on the dry matter content of a sample of the feed cut the previous evening and dried at $90{ }^{\circ} \mathrm{C}$ in a fan-forced oven overnight. Any refused feed was weighed to determine daily feed intakes, before being discarded.

Urine and faecal matter was separated using finemeshed cloth and collected into receptacle containers under each metabolism crate. Total faeces weight and urine volume/animal were determined daily for 3 days. Dry matter percentage of individual animal daily faecal samples were determined by drying duplicate samples to a constant weight in a fan-forced oven at $90{ }^{\circ} \mathrm{C}$ for $48 \mathrm{~h}$.

Data for each animal were averaged over all 3 days. Data for forages within treatments were averaged and means analysed by unbalanced analysis of variance using GenStat Version19 (VSN International Ltd, Hemel Hempstead, UK) with individual animals as random effects and treatment as fixed effects. To determine differences among treatments a Fisher's least significant difference test was performed.

\section{Nitrification inhibition}

Urine was also collected from sheep, using procedures approved by the Lincoln University Animal Ethics Committee, for use in a laboratory soil incubation experiment. Sheep (Romney ewe lambs, averaging about $45 \mathrm{~kg})$ grazed either perennial ryegrass $(\mathrm{n}=10)$ (cultivar 'Ceres $\mathrm{One}^{50}$ ') or plantain $(\mathrm{n}=10)$ (cultivar 'Agritonic') for 14 days before urine collection. Urine collection was carried out in a sheep handler and stored separately in a specimen jar. Immediately following collection, urine samples from each animal were transferred to the laboratory and was analysed for total $\mathrm{N}$ after persulfate oxidation (Cabrera \& Beare 1993) and determination on a Lachat Instruments QuikChem 8500 Series 2 Flow Injection Analysis System (Loveland, CO, USA).

A Templeton silt loam soil from a low-input ungrazed Italian ryegrass (Lolium multiflorum cultivar 'Andy') pasture was used to conduct a soil incubation experiment. Multiple soil cores ( $0-5 \mathrm{~cm}$ depth) collected at the Plant \& Food Research farm, at Lincoln, Canterbury, were mixed thoroughly to form a composite sample, before passing through a $4 \mathrm{~mm}$ sieve and air-drying.

Soil microcosms ( $70 \mathrm{ml}$ plastic vials containing $20 \mathrm{~g}$ of air-dried equivalent soil), were used to evaluate soil nitrification following deposition of urine from sheep fed different diets. Before adding to soil, the urine collected from sheep (replicates) was bulked to provide sufficient volume of a homogenous composition for experimental use. The urine from the ryegrass-fed sheep was diluted with water to standardise the treatments and match the $\mathrm{N}$ concentration in the urine of those fed plantain (since the plantain-fed animals produced urine with considerably lower total $\mathrm{N}$ concentration). Urine was added to soil drop-wise $(6.3 \mathrm{ml}$ added using an electronic pipette in titrate mode) to bring the soil to field capacity (defined here as the soil moisture content at $-10 \mathrm{kPa}$ ). Water in the place of urine was added to additional microcosms to provide a control treatment.

The microcosms were covered with Parafilm ${ }^{\circledR}$ which was pierced to allow for gas diffusion. Microcosms, for destructive sampling, were placed in $5.5 \mathrm{~L}$ boxes in a specially designed split-plot arrangement in an incubator set at $20^{\circ} \mathrm{C}$. During the incubation, the soil was maintained at $-10 \mathrm{kPa}$ by the addition of water, as required.

Experimental replicates of each treatment (plantain or perennial ryegrass urine) were destructively sampled to determine the net nitrification rate after 1, 7, 14, 21, 28 and 35 days (three replicates/treatment/destructive sampling time). At each time point, $5 \mathrm{~g}$ of soil from each replicate was used to measure inorganic $\mathrm{N}\left(\mathrm{NH}_{4}^{+}-\mathrm{N}\right.$ and $\mathrm{NO}_{3}{ }^{-} \mathrm{N}$ ) by shaking the soil with $2 \mathrm{M} \mathrm{KCl}$ (soil/solution ratio 1:5) for $1 \mathrm{~h}$. The soil suspensions were centrifuged at $4000 \mathrm{rpm}$ for 5 minutes and the supernatant filtered through a pre-leached Munktell 393 (Munktell Inc., Raleigh, NC, USA) filter paper before analysis by a Lachat QuickChem flow injection analyser.

Statistical tests were performed using Genstat 64-bit Release 19.1 (VSN International Ltd, Hemel Hempstead, UK). Differences between treatment means were tested by one-way analysis of variance (ANOVA), and if treatment effects were found to be significant $(\mathrm{P}<0.05)$, the least significant difference $\left(\mathrm{LSD}_{5 \%}\right)$ was used to separate means. 


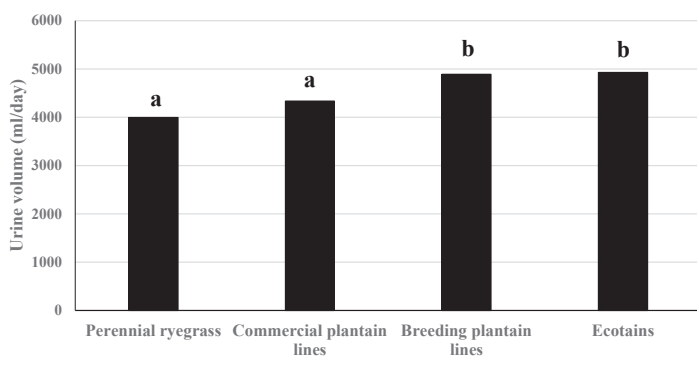

Figure 1 Urine volume $(\mathrm{ml})$ from ewe lambs fed plantain genotypes: commercial lines (6) breeding lines (4) and Ecotains (2) and ryegrass, balanced for water intake. Letters represent significant differences between the means.

\section{Results}

\section{Diuretic potency}

Treatments (plantain cultivars) were grouped into (1) commercial plantain lines $(n=6$, 'Hercules', 'Endurance', 'Ranger', 'Tuatara', 'Boston' and 'Lancelot'), (2) breeding lines of plantain with a genetic relationship to the "Ecotains" ( $\mathrm{n}=4$ : 'PG734', 'PG702', 'Elite 18' and 'PG718') and (3) "Ecotains" (n=2: 'Tonic', 'Agritonic'). Dry matter percentage was lower on average for breeding lines and "Ecotains" (13\%) than for commercial cultivars and grass $(15 \%)$ and therefore on average $1.03 \mathrm{~L}$ more water was applied externally to the latter. Animals fed "Ecotains" and breeding lines produced significantly more urine $(4925$ and $4887 \mathrm{ml} /$ day, respectively) than those fed commercial plantain lines $(4333 \mathrm{ml} /$ day) or ryegrass $(3993 \mathrm{ml} /$ day) (Figure 1). Animals consuming ryegrass produced the least urine, although this was not significantly different from the volume of urine produced by animals consuming commercial lines. Water content of faeces was $75 \%$ of fresh weight and did not differ between treatments.

\section{Nitrification inhibition}

The average total $\mathrm{N}$ measured in the urine produced by sheep fed ryegrass was $9.9 \mathrm{~g} \mathrm{~N} / \mathrm{L}(1563 \mathrm{mg} \mathrm{N} / \mathrm{kg})$ compared to $2.2 \mathrm{~g} \mathrm{~N} / \mathrm{L}(802 \mathrm{mg} \mathrm{N} / \mathrm{kg})$ found in the urine of sheep fed plantain (cultivar 'AgriTonic'). When applied to soil, $13 \%$ of the total $\mathrm{N}$ in the plantain urine was in ammonium form, whilst the ryegrass urine contained only $0.6 \%$ ammonium. Yet within 24 hours, $96 \%$ percent of the total urine $\mathrm{N}$ added (in both the plantain and the ryegrass treatments) had hydrolysed to ammonium.

When the diluted urine $(802 \mathrm{mg} \mathrm{N} / \mathrm{kg}$ ) from ryegrass fed sheep was applied to microcosms, nitrate accumulated quickly, such that at 21 days post-application, almost $50 \%$ of urinary $\mathrm{N}$ had been converted to nitrate via the process of nitrification (Figure 2). The full rate of urine from sheep fed plantain $(802 \mathrm{mg} \mathrm{N} / \mathrm{kg}$ ) created a quite different response with a much slower nitrification rate overall and especially in the first 28 days post-

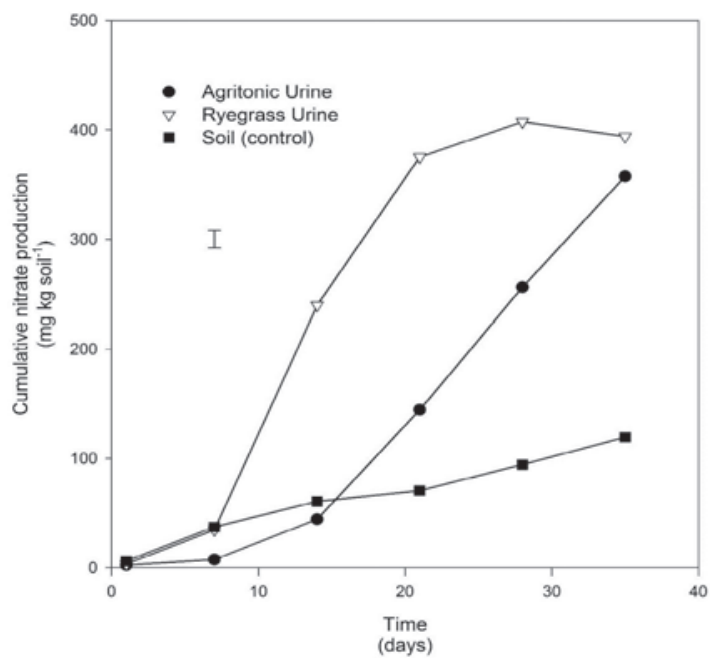

Figure 2 Cumulative amounts of nitrate produced (mg/ $\mathrm{kg}$ soil) in urine from 'Agritonic' and ryegrass-fed sheep during the soil incubation over time. Bar represents the $\mathrm{LSD}_{5 \%}$.

application where a significantly lower proportion of the urinary $\mathrm{N}$ was converted to nitrate.

\section{Discussion}

\section{Diuretic potency}

In the indoor sheep study, feed was allocated on a DM basis and water was added to the surface of the feed to ensure all animals had similar water intakes. The increase in urine volume for sheep fed various plantains suggests a diuretic effect since faecal water content was similar across treatments, confirming previous findings (O'Connell et al. 2016). However, this experiment also suggests the diuretic potency of plantain was genotype-specific. The mechanisms driving increased diuresis by sheep fed both plantain breeding lines and "Ecotains" are unclear, but may be related to the presence of secondary compounds in the feed. The presence of secondary plant compounds in plantain herbage is genotype specific (Al-Mamun et al. 2008; Box \& Judson 2018) providing a possible explanation for the differences in urine volume among the genotypes evaluated here. These results suggest that selection of specific plantain genotypes may reduce urinary $\mathrm{N}$ concentration by increasing urine volume thereby diluting urinary $\mathrm{N}$, and reducing the risk of $\mathrm{N}$ leaching from grazing systems.

\section{Nitrification inhibition}

Urine from sheep fed one of the "Ecotains" reduced the rate of nitrification from urine in the 28 days after application compared with sheep fed ryegrass. This suggests a nitrification inhibitor(s) exist in the urine of sheep fed plantain. The lower populations of ammonium 
oxidising bacteria in soils treated with urine from cows grazing plantain (Carlton et al. 2018) could be a plausible explanation for this observation and current results suggest this effect may also apply to sheep. If the urine of ryegrass-fed sheep had been applied at full rather than at diluted rate (i.e. $1563 \mathrm{mg} \mathrm{N} / \mathrm{kg}$ rather than $802 \mathrm{mg} \mathrm{N} / \mathrm{kg}$ ), an even greater amount of nitrate would have been released via nitrification, as found by Dai et al. (2013). Slowing the rate of nitrification can be useful tool in reducing nitrate leaching, as it increases the time plants in the urine patch to absorb nitrogen before it is converted into the leachable nitrate form. Such an effect is likely to be particularly important in free-draining soils with regular water movement through the profile promoting leaching.

Sheep consuming "Ecotains" reduce the potential for nitrate leaching via reduced urinary $\mathrm{N}$ concentration resulting from increased urine volume, and through a reduction in the rate at which urinary $\mathrm{N}$ is converted to nitrate in the urine patch.

\section{ACKNOWLEDGEMENTS}

Lou Buick, Abi Huddleston and Amanda Pawsey for technical assistance, David Baird for statistical analysis and Callaghan Innovation for funding.

\section{REFERENCES}

Box, L.A.; Judson, H.G. 2018. The concentration of bioactive compounds in Plantago lanceolata is genotype specific. Journal of New Zealand Grasslands 80: 113-118.

Cabrera, M.L.; Beare, M.H. 1993. Alkaline persulfate oxidation for determining total nitrogen in microbial biomass extracts. Soil Science Society of America Journal 57: 1007-1012.

Carlton, A.J.; Cameron, K.C.; Di, H.J.; Edwards, G.R.; Clough, T.J. 2018. Nitrate leaching losses are lower from ryegrass white clover pastures containing plantain than from ryegrass white clover forages under irrigation. New Zealand Journal of Agricultural Research DOI 10.1080 00288233.2018.1461659.
Dai, Y.; Di, H.J.; Cameron, K.C.; He, J-Z. 2013. Effects of nitrogen application rate and a nitrification inhibitor dicyandiamide on ammonia oxidizers and $\mathrm{N}_{2} \mathrm{O}$ emissions in a grazed pasture soil. Science of the Total Environment 465: 125-135.

Judson, H.G.; McAnulty, R.; Sedcole R. 2009. Evaluation of 'Ceres Tonic' plantain (Plantago lanceolata) as a lactation feed for twin-bearing ewes. Proceedings of the New Zealand Grassland Association 71: 201-205.

Kemp, P.D.; Kenyon, P.R.; Morris, S.T.; Somasiri S.C. 2013. Plantain (Plantago lanceolata) in herb and legume pastures increases lamb growth relative to perennial ryegrass while clover pasture. Proceedings of the 22nd International Grasslands Congress: 561562.

Kenyon P.R.; Kemp P.D.; Stafford K.J.; West D.M.; Morris S.T. 2010. Can a herb and white clover mix improve the performance of multiple bearing ewes and their lambs to weaning? Animal Production Science 50: 513-521.

Ledgard, S.; Schils, R.; Eriksen, J.; Luo, J. 2009. Environmental impact of grazed clover/grass pastures. Irish Journal of Agriculture and Food Research 48: 209-226.

Moorhead, A.J.E.; Judson, H.G.; Stewart, A.V. 2002. Liveweight gain of lambs grazing Ceres Tonic plantain (Plantago lanceolata) or perennial ryegrass (Lolium perenne). Proceedings of the New Zealand Society of Animal Production 62: 171-173.

O'Connell, C.A.; Judson, H.G.; Barrell, G.K. 2016. Sustained diuretic effect of plantain when ingested by sheep. Proceedings of the New Zealand Society of Animal Production 76: 14-17.

Stewart, A.V. 1996. Plantain (Plantago lanceolata) - a potential pasture species. Proceedings of the New Zealand Grassland Association 58: 77-86.

Totty, V.K.; Greenwood, S.L.; Bryant, R.H.; Edwards, G.R. 2013. Nitrogen partitioning and milk production of dairy cows grazing simple and diverse pastures. Journal of Dairy Science 96: 141-149. 